\title{
Heavy Metals Content in Water and Crops in Golding Mining Vicinity on Major Dams in Zamfara State, Nigeria
}

\author{
"MOSES, S; AGBAJI, EB; AJIBOLA, VO; GIMBA, CE
}

\author{
Department of Chemistry, Ahmadu Bello University, Zaria, Nigeria \\ *Corresponding Author Email: akamomoses@yahoo.com
}

\begin{abstract}
The concentrations of heavy metals in water and food crops (tomatoes and cassava) grown around the three major dams in Zamfara State were gold mining are usually done were determined using standard methods. The concentration of heavy metal determined in water and food crops were generally high during the dry season with exception of $\mathrm{Hg}$ which recorded its highest concentration in year 2015. $\mathrm{Zn}$ and $\mathrm{Cr}$ levels in the water and food crops were within international safe limits while $\mathrm{Cd}, \mathrm{Pb}$ and $\mathrm{Hg}$ levels were far above $(0.01,0.01$ and $0.001 \mathrm{mg} / \mathrm{l}) \mathrm{WHO}$ and USEPA limits respectively. In this work, the concentration of the analyzed heavy metals in $\mathrm{mg} / \mathrm{l}$ was in the order of $\mathrm{Hg}>\mathrm{Pb}>\mathrm{Cd}>\mathrm{Cr}>\mathrm{Zn}$. Correlation analysis showed a significant and positive relationship for $\mathrm{Cd}$ and $\mathrm{Zn}$ and $\mathrm{Hg}$ and $\mathrm{Cr}$ during the wet season and a significant positive at the ( $\mathrm{p}>0.05$ ) relationship for $\mathrm{Cr}$ and $\mathrm{Zn}$ in the dry season. The pollution index value of the water samples across all the three dams indicated that there is need for immediate intervention to ameliorate pollution particularly in the dry season
\end{abstract}

\section{DOI: https://dx.doi.org/10.4314/jasem.v22i6.22}

Copyright: Copyright $\odot 2018$ Moses et al. This is an open access article distributed under the Creative Commons Attribution License (CCL), which permits unrestricted use, distribution, and reproduction in any medium, provided the original work is properly cited.

Dates: Received: 16 April 2018; Revised: 24 June: 2018; Accepted: 30 June 2018

Keyword: Dams, Heavy metals, food crops, gold mining

Environmental pollution by toxic heavy metals does not only elicit concern in the metropolitan cities but also in remote and rural communities where anthropogenic activities, such as mining, are taking place. Gold mining and processing have been the main sources of heavy metal contamination in the environment (Duruibe et al., 2007; Boamponsem et al., 2010; Girigisu et al., 2012). The uncontrolled dissemination of waste effluents to large water bodies has negatively affected both water quality and aquatic life (Abdulrahman, et al., 2008). During the processing of the ores for gold, poisonous substances such as oxides and sulphides of heavy metal pollutants are released into the environment Boamponsem et al., (2010). Hence, most of the water sources particularly in Zamfara State are gradually becoming polluted due to the addition of these foreign materials from the environment. Artisan mining is an important economic sector in many developing countries. However, limited resources and training, and the availability of cheap, but potentially hazardous methods of extraction and processing of minerals can cause significant threats to both miners and the local environment (Bitala, 2008; Armah et al., 2010). Such a scenario is being experienced in mining locations in Zamfara State. During peak mining periods, up to 5000 people invade the mining areas from outside the State. This has devastating effects on health and environment. Artisan mining in these areas conforms to neither mining laws nor regulations governing mining operations and environmental management. Studies in a similar region, in Tanzania revealed that symptoms of heavy metal poisoning such as sensory disturbance, hyporeflexia, tremor, gingivitis, metallic taste, neuroasthenia and night blindness are common (Harada et al., 1997; Akabzaa, 2000; Lottermoser, 2007). There have been several reports on acute lead $(\mathrm{Pb})$ poisoning outbreak among the dwellers of some remote villages of Zamfara State, Nigeria. This has been linked to the illegal mining operations by the people of remote communities (Galadima, 2012). Mercury as a pollutant in artisan mining is due mainly to gold processing, when mercury is used to amalgamate gold. Cadmium, which is another common toxic metal, occupying position seven in the priority list of hazardous substances (ATSDR, 1999), generally occurs as an isometric trace element in sphalerite. Cadmium levels are likely to be quite low. Large amounts of $\mathrm{Hg}$ are released into the environment as a result of its usage in gold extraction. About $1.32 \mathrm{~kg}$ of $\mathrm{Hg}$ is lost for every $1 \mathrm{~kg}$ of gold produced which goes directly into water, soil and streams as inorganic $\mathrm{Hg}$ and later converted into organic forms (Matshusa et al., 2012). Several researchers have reported on its high concentration in gold mine tailings. Rafiei et al., (2010) reported 100 $\mathrm{mg} / \mathrm{kg}$ concentrations of $\mathrm{Hg}$ in Iran whereas Mathusa et al., (2012) reported concentrations as high as 1920 
$\mathrm{mg} / \mathrm{kg}$ in Kenya. Some of the inorganic $\mathrm{Hg}$ that reaches aquatic ecosystems is converted by microbes into organic methylmercury $(\mathrm{MeHg})$, which accumulates in fish. Mercury compounds cause oxidative stress to bacterial cells due to imbalance between pro-oxidant and anti-oxidant homeostasis. They have high affinity for thiol group containing enzymes and proteins that serve as a line of cellular defense against $\mathrm{Hg}$ compounds. On gaining access to the cell, both $\mathrm{Hg}$ II $\left(\mathrm{Hg}^{2+}\right)$ and $\mathrm{MeHg}$ form covalent bonds with cysteine residues of proteins and deplete cellular antioxidants (Valko et al., 2006). The aim of the research is to investigate the levels of heavy metals in gold mining areas within the three major dams and food crops grown around the dams in Zamfara State, Nigeria.

\section{MATERIALS AND METHODS}

In the preparation of solution, analytical reagent grade chemicals and distilled water were used. All glassware were washed with detergent and rinsed in water before immersion in $10 \%$ nitric acid solution. They were further rinsed with distilled water before drying in the oven (Ayodele et al., 1994).

Description of the Sampling Area: Zamfara State is located in the North Western Zone of Nigeria between Latitude $11^{\circ} 40^{\prime} \mathrm{E}$ and Longitudes $70^{\circ} 25^{\prime} \mathrm{E}$ with an altitude of $420 \mathrm{~m}$. The state inherited three major dams from the former Sokoto State in the quest to provide potable water for the teeming population. The dams are located in Gusau LGA (Gusau dam), Maradun LGA (Bakolori dam), and Maru LGA (Dangulubi dam). The dams are considered for investigation as a result of lead poisoning epidemic that struck the state sometimes around year 2010 . The dams became very necessary to investigate because mining activities are still going on across the state in which water from the dams are used in the mining processes and more so because livestock are seen drinking from the dams and plants are sited growing around the vicinity of the mining areas.

Treatment of Sampling Containers: A one-liter polythene bottle was used for the collection of water sample. It was thoroughly washed with detergent solution, rinsed with distilled water and then leached with $10 \% \mathrm{HNO}_{3}$ and 1:1 $\mathrm{HCI}$ for 48 hours. The bottle was then rinsed with distilled water and allowed to drain to dryness. Polythene containers used for the collection of food crops and was treated similarly.

Collection of Water Samples from the Dams: The water samples were collected by dipping a two litre plastic bottle just below the water surface at a depth of one meter from each of the six sampling locations. Precleaned 2 litre polyethylene sampling bottles were used for sampling. At each sampling locations, the bottles were rinsed 3 times with the water before collection of the sample. The samples were preserved by acidifying with $2 \mathrm{ml}$ of concentrated $\mathrm{HNO}_{3}$ in order to achieve a $\mathrm{pH}$ of 2 and prevent metal adsorption onto the inner surface of the container. Digestion of Water Samples for Heavy Metal Analysis and food such as tomatoes and cassava was done according to the method by APHA, 2005.

Contamination factor $(C F)$ : The Contamination factor $(\mathrm{CF})$ is the ratio obtained by dividing the concentration of each metal in the sediment, water and fish samples by

$C F=\frac{\text { concentration of metal in sample }}{\text { concentration of metal in background }}$

In this study, the WHO (2004) guidelines values for drinking water quality were selected as background level for the calculation of contamination factors of the water samples. The contamination levels may be classified based on their intensities on a scale ranging from 1 to $6(0=$ none, $1=$ none to medium, $2=$ moderate, $3=$ moderately to strong, $4=$ strongly polluted, $5=$ strong to very strong, $6=$ very strong) (Bhuiyan et al., 2010 and Harikumar et al., 2010). The $\mathrm{CF}$ value of 6 indicates that the metal concentration is 100 times greater than what would be expected in the world average shale (Wedepohl, 1995).

Pollution Load Index (PLI): The PLI was obtained as a concentration factor of each heavy metal with respect to the background value in the samples.

According to Angula (1996) the PLI is able to give an estimate of the metal contamination status and the necessary action that should be taken, where $\mathrm{CF}_{1}$ to $\mathrm{CF}_{\mathrm{n}}$ indicate the contamination factors calculated for the first sample to the $\mathrm{n}^{\text {th }}$ one. A PLI value close to one indicates heavy metal loads near the background level, while values above one indicate sample pollution (Bhupander et al., 2011; Angula, 1996).

$$
P L I=\sqrt[n]{C F 1 \times C F 2 \times C F 3 \times C F 4 \ldots X C F n}
$$

\section{RESULTS AND DISCUSSION}

The concentration of $\mathrm{Pb}$ and $\mathrm{Hg}$ in the water samples (Table 1) from this water bodies exceeded the permissible limit of 0.05 and $0.001 \mathrm{mg} / \mathrm{L}$ respectively set by (WHO, 2004; USEPA, 2002). In this work, the concentration of the analyzed heavy metals in $\mathrm{mg} / \mathrm{l}$ was in the order of $\mathrm{Hg}>\mathrm{Pb}>\mathrm{Cd}>\mathrm{Cr}>\mathrm{Zn}$. The 
abnormal high contamination factor (CF) level (table 3 ) of $\mathrm{Hg}$ was expected across all the three dams since gold processing is still very active in these areas. The higher contamination factor for all the heavy metals during the dry season might be due to seasonal rainfall which dilutes some concentration of the metal concentration during the wet season. The pollution index value of the water samples across all the three dams indicated that there is need for immediate intervention to ameliorate pollution particularly in the dry season. Generally, the natural sources of heavy metals in rivers and dams, Marine and Coastal water are through land, heavy fresh water inflow, agricultural waste, aquaculture discharge and river run-offs and the mechanical and chemical weathering of rocks (Ashokkumar et al., 2009). Correlation analysis (Tables $2 \mathrm{a}$ and $\mathrm{b}$ ) showed a significant and positive relationship for $\mathrm{Cd}$ and $\mathrm{Zn}$ and $\mathrm{Hg}$ and $\mathrm{Cr}$ during the wet season and a significant positive at the ( $\mathrm{p}>0.05$ ) relationship for $\mathrm{Cr}$ and $\mathrm{Zn}$ in the dry season. Similar observation was reported on the study of heavy metals in Ureje dam in Ado-Ekiti by Adefemi et al. (2007) and in Kanji dam (Amoo et al., 2005) and other studies on surface water (Chapman, 1999; Asaolu et al., 1997; Karadede et al., 2000)

Table 1: Heavy Metals Concentrations (mg/l) of Water Samples for Two wet and dry Seasons

\begin{tabular}{|c|c|c|c|c|c|c|}
\hline location & vear & $\mathrm{Z}_{\mathbf{n}}$ & $\mathrm{Cd}$ & $\mathrm{Cr}$ & $\mathrm{Pb}$ & $\mathrm{He}$ \\
\hline \multirow[t]{2}{*}{ Ll wet } & 2014 & $0.0020 \pm 0.0001$ & $0.0040 \pm 0.0001$ & $0.0210=0.0003$ & $0.0918=0.0004$ & $0.2638=0.000$ \\
\hline & 2015 & $0.0024 \pm 0.0001$ & $0.0036 \pm 0.0002$ & $0.0262 \pm 0.0040$ & $0.0029=0.0001$ & $1.5532=0.003$ \\
\hline \multirow[t]{2}{*}{ L.2 wet } & 2014 & $0.0060 \pm 0.0001$ & $0.0064=0.0003$ & $0.0078=0.0003$ & $0.0476 \pm 0.0020$ & ND \\
\hline & 2015 & $0.0066 \pm 0.0001$ & $0.0024=0.0002$ & $0.0044=0.0003$ & $0.0068 \pm 0.0001$ & $0.5005=0.003$ \\
\hline \multirow[t]{2}{*}{ L3 wet } & 2014 & $0.0042 \pm 0.0002$ & $0.0024=0.0001$ & $0.0014=0.0004$ & 0.0 & $\mathrm{ND}$ \\
\hline & 2015 & $=0.0003$ & $0.0066 \pm 0.0005$ & $0.0042 \pm 0.0002$ & 20 & $0.5308=0.003$ \\
\hline \multirow[t]{2}{*}{ Ll dry } & 2014 & $0.0244 \pm 0.0002$ & $0.0904=0.0001$ & $0.0682 \pm 0.0030$ & 0.1376 & $\mathrm{ND}$ \\
\hline & 2015 & $0.0112=0.0020$ & $0.2044=0.0020$ & $0.0694=0.0040$ & $0.0062=0.0001$ & 1.55 \\
\hline \multirow[t]{2}{*}{ L2 dry } & 2014 & $0.0068=0.0001$ & $0.0740=0.0003$ & $0.0034=0.0003$ & $0.0876 \pm 0.0020$ & $\mathrm{ND}$ \\
\hline & 2015 & $0.0266 \pm 0.0010$ & $0.0744=0.0020$ & $0.0304=0.0030$ & $0.1314=0.0010$ & $0.5573=0.003$ \\
\hline \multirow[t]{2}{*}{ L3 dry } & 2014 & $0.0076 \pm 0.0002$ & $0.0550 \pm 0.0010$ & $0.1090=0.0040$ & $0.0334=0.002$ & $\mathrm{ND}$ \\
\hline & 2015 & $0.0118=0.0030$ & $0.0140=0.0050$ & $0.1098 \pm 0.0020$ & $0.0668 \pm 0.0020$ & $0.8506 \pm 0.003$ \\
\hline
\end{tabular}

Concentrations of heavy metal in tomatoes and cassava (Table 4 and 5) in this work revealed spatial variation at all three dams during the study periods. The relative abundance of different metals at the three locations during the wet and dry seasons varied with locations and with season in the tomatoes and cassava samples.

Table 2a: Correlation matrix of Heavy Metals Concentrations (mg/l) in Water Samples for Two Wet seasons

\begin{tabular}{llllll}
\hline \multicolumn{7}{c}{ Correlations } & Forwet & & & & \\
& $\mathbf{Z n}$ & $\mathbf{C d}$ & $\mathbf{C r}$ & $\mathrm{Pb}$ & $\mathbf{H g}$ \\
$\mathbf{Z n}$ & 1 & & & & \\
$\mathbf{C d}$ & $.394^{*}$ & 1 & & & \\
$\mathbf{C r}$ & -.130 & -.074 & 1 & & \\
$\mathbf{P b}$ & -.021 & -.128 & -.102 & 1 & \\
$\mathrm{Hg}$ & -.023 & .280 & $.365^{*}$ & .034 & 1 \\
& 36 & 36 & 36 & 36 & 36 \\
\hline
\end{tabular}

*.Correlation is significant at the 0.05 level (2-tailed)

Table 2b: Correlation matrix of heavy Metals Concentrations (mg/l) in Water Samples for two dry seasons

\begin{tabular}{llllll}
\hline \multicolumn{1}{c}{ Correlations } & For dry & & & & \\
& $\mathbf{Z n}$ & $\mathbf{C d}$ & $\mathbf{C r}$ & $\mathbf{P b}$ & $\mathbf{H g}$ \\
$\mathbf{Z n}$ & 1 & & & & \\
$\mathbf{C d}$ & -.023 & 1 & & & \\
$\mathbf{C r}$ & $.565^{*}$ & -.247 & 1 & & \\
$\mathrm{~Pb}$ & .243 & -.306 & .056 & 1 & \\
$\mathrm{Hg}$ & -.017 & .233 & .025 & -.189 & 1 \\
& 36 & 36 & 36 & 36 & 36 \\
\hline
\end{tabular}

**. Correlation is significant at the 0.01 level (2-tailed).
Heavy metals are found naturally in the earth, and become concentrated as a result of human activities such as industrial production, mining, agriculture and transportation (Noorul et al., 2015; Bassey et al., 2014). These metals have positive and negative roles in human life (Noor-ul et al., 2015, Colak et al., 2005; Oktem et al., 2005).

For instance heavy metal such as copper, chromium, cobalt and zinc are essential micronutrients for higher animals and for plant growth (Manohara et al., 2014). Studies have revealed that fruits and leafy vegetables are vulnerable to heavy metal contamination from soil, waste water and air pollution (Manohara et al., 2014).

The presence and accumulation of the analyzed heavy metals in the cassava and tomatoes plants could be traced to their presence in the wastes used. Liu et al., 2005 opined that the soil type, 
root stock, mulching, irrigation, fertilization, and other cultural practices influence the water and nutrient supply to plant and affect the composition and quality attributes of the harvested parts. $\mathrm{Zn}$ is the least toxic among all heavy metals, and is an essential element in the human diet as it is required to maintain the proper functioning of the immune system, normal brain activity and is fundamental in the growth and development of the foetus.

Excessive $\mathrm{Zn}$ in the diet e.g. prolonged daily intake of $\mathrm{Zn}$ ranging from 150 - $450 \mathrm{mg} /$ day is also detrimental to human health (Johnson et al., 2007). This was also similar to the report by Kirmani et al., 2011 and Bosiacki et al., 2009, on the levels of $\mathrm{Zn}$ in onions, carrot, cabbage, and tomatoes above permissible levels by FAO/WHO.

Table 3: Heavy Metal Contamination Factors (CF) and Pollution Load Index (PLI) in Water for Wet and Dry Seasons

\begin{tabular}{lllllll}
\hline Location/WET & $\mathrm{Zn}$ & $\mathrm{Cd}$ & $\mathrm{Cr}$ & $\mathrm{Pb}$ & $\mathrm{Hg}$ & $\mathrm{PLI}$ \\
\hline Gusau dam & 0.0004 & 0.3800 & 0.2360 & 0.9470 & 90.8500 & 0.3206 \\
Bakolori dam & 0.0013 & 0.4400 & 0.0610 & 0.5440 & 50.0500 & 0.2486 \\
Dangulbi dam & 0.0009 & 0.4500 & 0.0280 & 0.6060 & 53.0800 & 0.2053 \\
DRY & & & & & & \\
Gusau dam & 0.0035 & 14.7400 & 0.6880 & 1.4380 & 155.700 & 1.5188 \\
Bakolori dam & 0.0033 & 7.4200 & 0.1690 & 2.1900 & 557.300 & 1.3858 \\
Dangulbi dam & 0.0019 & 3.4500 & 1.0940 & 1.0020 & 850.600 & 1.4423 \\
\hline
\end{tabular}

Table 4: Heavy Metals Concentrations (mg/kg) of Tomatoes Samples for wet and dry

\begin{tabular}{lllllll}
\multicolumn{7}{c}{ Seasons } \\
\hline location & year & Zn & Cd & Cr & Pb & Hg \\
\hline L1 wet & 2014 & $0.029 \pm 0.002$ & $0.019 \pm 0.001$ & $0.183 \pm 0.003$ & $0.261 \pm 0.004$ & $0.556 \pm 0.002$ \\
& 2015 & $0.024 \pm 0.002$ & $0.010 \pm 0.002$ & $0.010 \pm 0.004$ & $0.334 \pm 0.001$ & $1.746 \pm 0.003$ \\
L2 wet & 2014 & $0.039 \pm 0.001$ & $0.019 \pm 0.003$ & $0.261 \pm 0.003$ & $0.125 \pm 0.002$ & $0.163 \pm 0.000$ \\
& 2015 & $0.049 \pm 0.001$ & $0.012 \pm 0.002$ & $0.012 \pm 0.003$ & $0.396 \pm 0.001$ & $2.202 \pm 0.003$ \\
L3 wet & 2014 & $0.052 \pm 0.002$ & $0.014 \pm 0.001$ & $0.157 \pm 0.004$ & $0.271 \pm 0.002$ & $0.446 \pm 0.000$ \\
& 2015 & $0.056 \pm 0.003$ & $0.016 \pm 0.005$ & $0.016 \pm 0.002$ & $0.511 \pm 0.002$ & $0.600 \pm 0.003$ \\
L1 dry & 2014 & $0.036 \pm 0.002$ & $0.432 \pm 0.001$ & $0.364 \pm 0.003$ & $0.250 \pm 0.004$ & ND \\
& 2015 & $0.031 \pm 0.002$ & $0.256 \pm 0.002$ & $0.369 \pm 0.004$ & $0.365 \pm 0.001$ & $4.363 \pm 0.003$ \\
L2 dry & 2014 & $0.058 \pm 0.001$ & $0.216 \pm 0.003$ & $0.324 \pm 0.003$ & $1.074 \pm 0.002$ & ND \\
& 2015 & $0.041 \pm 0.001$ & $0.334 \pm 0.002$ & $0.314 \pm 0.003$ & $0.500 \pm 0.001$ & $2.527 \pm 0.003$ \\
L3 dry & 2014 & $0.093 \pm 0.002$ & $0.668 \pm 0.001$ & $1.165 \pm 0.004$ & $0.615 \pm 0.002$ & ND \\
& 2015 & $0.071 \pm 0.003$ & $0.354 \pm 0.005$ & $1.150 \pm 0.002$ & $0.644 \pm 0.002$ & $1.343 \pm 0.003$ \\
\hline
\end{tabular}

$n=3$; mean \pm S.D. key: $L 1=$ Gusau dam, L2= Bakolori dam and L3= Dangulbi dam

Table 5: Heavy Metals Concentrations ( $\mathrm{mg} / \mathrm{kg}$ ) of Cassava Samples for wet and dry Seasons

\begin{tabular}{lllllll}
\hline location & year & $\mathbf{Z n}$ & $\mathbf{C d}$ & $\mathbf{C r}$ & $\mathbf{P b}$ & $\mathbf{H g}$ \\
\hline L1 wet & 2014 & $0.177 \pm 0.002$ & $0.026 \pm 0.001$ & $0.111 \pm 0.003$ & $0.365 \pm 0.004$ & $\mathrm{ND}$ \\
& 2015 & $0.197 \pm 0.002$ & $0.019 \pm 0.002$ & $0.275 \pm 0.004$ & $0.155 \pm 0.001$ & $0.673 \pm 0.003$ \\
L2 wet & 2014 & $0.148 \pm 0.001$ & $0.013 \pm 0.003$ & $0.179 \pm 0.003$ & $0.189 \pm 0.002$ & $\mathrm{ND}$ \\
& 2015 & $0.158 \pm 0.001$ & $0.009 \pm 0.002$ & $0.190 \pm 0.003$ & $0.858 \pm 0.001$ & $1.195 \pm 0.003$ \\
L3 wet & 2014 & $0.074 \pm 0.002$ & $0.009 \pm 0.001$ & $0.190 \pm 0.004$ & $0.219 \pm 0.002$ & $\mathrm{ND}$ \\
& 2015 & $0.084 \pm 0.003$ & $0.005 \pm 0.005$ & $0.157 \pm 0.002$ & $0.462 \pm 0.002$ & $1.059 \pm 0.003$ \\
L1 dry & 2014 & $0.373 \pm 0.002$ & $0.963 \pm 0.001$ & $1.008 \pm 0.003$ & $0.851 \pm 0.004$ & $\mathrm{ND}$ \\
& 2015 & $0.183 \pm 0.002$ & $0.806 \pm 0.002$ & $1.018 \pm 0.004$ & $0.744 \pm 0.001$ & $0.874 \pm 0.003$ \\
L2 dry & 2014 & $0.249 \pm 0.001$ & $0.256 \pm 0.003$ & $0.529 \pm 0.003$ & $0.188 \pm 0.002$ & ND \\
& 2015 & $0.240 \pm 0.001$ & $0.197 \pm 0.002$ & $0.548 \pm 0.003$ & $1.636 \pm 0.001$ & $1.900 \pm 0.003$ \\
L3 dry & 2014 & $0.166 \pm 0.002$ & $0.629 \pm 0.001$ & $0.859 \pm 0.004$ & $0.977 \pm 0.002$ & $\mathrm{ND}$ \\
& 2015 & $0.087 \pm 0.003$ & $0.747 \pm 0.005$ & $0.867 \pm 0.002$ & $1.012 \pm 0.002$ & $1.902 \pm 0.003$ \\
\hline
\end{tabular}

$n=3$; mean \pm S.D. key: $L 1=$ Gusau dam, L2= Bakolori dam and L3= Dangulbi dam

The concentration of the heavy metal reported in the present study are lower than the one reported by Kakulu (1985) for Niger Delta, Okoye (1989) for Lagoon and that which was reported by Asaolu (1998) for Ondo State Coastal area. Average $\mathrm{Pb}$ level for this study are higher than the average value of $0.50 \mu \mathrm{g} / \mathrm{g}$ which was obtained in a similar study along the highways of Benue State Nigeria (Adebayo O. and Rapheal, 2011) and also higher than $1.73 \mu \mathrm{g} / \mathrm{g}$ in cassava tubers recorded by Nkwocha et al (2012) in an oil field in Bayelsa State. These values are unusually high and it's reflective of the anthropogenic activities around the dams.

The calculated contamination factor (CF) (table 7 and 9) revealed that only $\mathrm{Hg}$ had $\mathrm{CF}$ values greater 6 , which indicates a serious contamination of tomatoes harvested from all the location. The pollution load index (PLI) across all the locations had PLI values less than 1 .

This indicates that there is no serious overall pollution load on the tomatoes samples. While in cassava sample, the calculated contamination factor (CF) for all the heavy metals with exception of $\mathrm{Zn}$ is very high, this showed the level of contamination of the samples.

While the pollution load index (PLI) for all the location showed serious overall load of pollution on the sample.

Pearson correlation analysis (Tables $6 \mathrm{a}$ and $\mathrm{b} ; 8 \mathrm{a}$ and $\mathrm{b}$ ) conducted to examine whether there is a relationship between the heavy metal concentrations in the tomatoes and cassava tubers for two wet and dry seasons revealed a significant positive relationship for $\mathrm{Cr}$ and $\mathrm{Cd}$, $\mathrm{Cd}$ and $\mathrm{Zn}, \mathrm{Hg}$ and $\mathrm{Pb}$ in the wet season and a significant and positive relationship for $\mathrm{Cr}$ and $\mathrm{Cd}$, and $\mathrm{Pb}$ and $\mathrm{Cr}$ for dry season.

Conclusion: The levels of the metals in the water bodies were generally high with exception of $\mathrm{Zn}$ metal which should cause trepidation to both the aquatic lives and human health, hence calling for urgent regular monitoring of the dam and control of anthropogenic input into the water bodies. The pollution level of all the three dams and sample was accessed using the contamination factor (CF) and pollution load index (PLI), which revealed that all the water bodies have suffered from metal pollution. 
Table 6a: Correlation matrix of Heavy Metals Concentrations (mg/l) in Tomatoes Samples for two wet seasons

\begin{tabular}{|c|c|c|c|c|c|}
\hline Correlations & For wet & & & & \\
\hline & Zn & Cd & $\mathrm{Cr}$ & $\mathbf{P b}$ & $\mathrm{Hg}$ \\
\hline Zn & 1 & & & & \\
\hline Cd & $.416^{*}$ & 1 & & & \\
\hline $\mathrm{Cr}$ & .128 & $.471^{* *}$ & 1 & & \\
\hline $\mathbf{P b}$ & .166 & $-.350^{*}$ & $-.429^{* *}$ & 1 & \\
\hline $\mathrm{Hg}$ & $.375^{*}$ & $-.414^{*}$ & $-.709^{* *}$ & .277 & 1 \\
\hline & 36 & 36 & 36 & 36 & 36 \\
\hline
\end{tabular}

Table 6b: Correlation matrix of Heavy Metals Concentrations (mg/l) in Tomatoes Samples for two dry seasons

\begin{tabular}{llllll}
\hline Correlations & $\begin{array}{l}\text { For dry } \\
\mathbf{Z n}\end{array}$ & $\mathbf{C d}$ & $\mathbf{C r}$ & $\mathbf{P b}$ & $\mathbf{H g}$ \\
\hline $\mathbf{Z n}$ & 1 & & & & \\
$\mathbf{C d}$ & $.416^{*}$ & 1 & & & \\
$\mathbf{C r}$ & .128 & $.471^{* *}$ & 1 & & \\
$\mathbf{P b}$ & .166 & $-.350^{*}$ & $-.429^{* *}$ & 1 & \\
$\mathbf{H g}$ & $-.375^{*}$ & $-.414^{*}$ & $-.709^{* *}$ & .277 & 1 \\
& 36 & 36 & 36 & 36 & 36 \\
\hline
\end{tabular}

*.Correlation is significant at the 0.05 level (2tailed). **.Correlation is significant at the 0.01 level (2tailed).

Table 7: Heavy Metal Contamination Factors (CF) and Pollution Load Index (PLI) in Tomatoes for Wet and Dry Seasons

\begin{tabular}{lllllll} 
Location/WET & Zn & Cd & Cr & Pb & Hg & PLI \\
Gusau dam & 0.0026 & 0.1050 & 0.0029 & 0.0383 & 6.1667 & 0.0453 \\
Bakolori dam & 0.0005 & 0.0443 & 0.0016 & 0.0164 & 6.0033 & 0.0206 \\
Dangulbi dam & 0.0006 & 0.0653 & 0.0018 & 0.0354 & 2.4000 & 0.0225 \\
DRY & & & & & & \\
Gusau dam & 0.0053 & 1.5733 & 0.0132 & 0.1108 & 10.7567 & 0.1671 \\
Bakolori dam & 0.0015 & 2.4250 & 0.0054 & 0.0204 & 2.9867 & 0.0662 \\
Dangulbi dam & 0.0011 & 1.2450 & 0.0069 & 0.0430 & 8.5833 & 0.0915 \\
\hline
\end{tabular}

Table 8a: Correlation matrix of Heavy Metals Concentrations (mg/l) in Cassava Samples for Two Wet seasons

\begin{tabular}{llllll}
\hline Correlations & For wet & & & & \\
\hline $\mathbf{Z n}$ & $\mathbf{Z n}$ & $\mathbf{C d}$ & $\mathbf{C r}$ & $\mathbf{P b}$ & $\mathbf{H g}$ \\
$\mathbf{C d}$ & 1 & & & & \\
$\mathbf{C r}$ & $.357^{*}$ & 1 & & & \\
$\mathbf{P b}$ & .278 & .138 & 1 & & \\
$\mathbf{H g}$ & .277 & .080 & .052 & 1 & 1 \\
& .121 & -.262 & .320 & $.646^{* *}$ & \\
& 36 & 36 & 36 & 36 & 36
\end{tabular}

*.Correlation is significant at the 0.05 level (2-tailed). **.Correlation is significant at the 0.01 level (2-tailed).

Table 8b: Correlation matrix of Heavy Metals Concentrations (mg/l) in Cassava Samples for Two Dry seasons

\begin{tabular}{llllll}
\hline Correlations & $\begin{array}{c}\text { For dry } \\
\text { Zn }\end{array}$ & Cd & Cr & Pb & Hg \\
\hline $\mathbf{Z n}$ & 1 & & & & \\
$\mathbf{C d}$ & .165 & 1 & & & \\
$\mathbf{C r}$ & 173 & $.495^{* *}$ & 1 & & \\
$\mathbf{P b}$ & .086 & .328 & $.619^{* *}$ & 1 & \\
$\mathbf{H g}$ & .173 & -.157 & .095 & .169 & 1 \\
& 36 & 36 & 36 & 36 & 36 \\
\hline
\end{tabular}

**.Correlation is significant at the 0.01 level (2tailed).

Table 9: Heavy Metal Contamination Factors (CF) and Pollution Load Index (PLI) in Cassava for Wet and Dry Seasons

\begin{tabular}{lllllll}
\hline Location/Wet & $\mathrm{Zn}$ & $\mathrm{Cd}$ & $\mathrm{Cr}$ & $\mathrm{Pb}$ & $\mathrm{Hg}$ & $\mathrm{PLI}$ \\
\hline Gusau dam & 0.0037 & 2.2500 & 1.9300 & 26.000 & 0673 & 3.0954 \\
Bakolori dam & 0.0031 & 1.1000 & 1.8450 & 52.3500 & 1195 & 3.2930 \\
Dangulbi dam & 0.0016 & 0.7000 & 1.7350 & 34.0500 & 1059 & 2.3335 \\
Dry & & & & & & \\
Gusau dam & 0.0056 & 88.4500 & 10.6300 & 79.7500 & 0874 & 12.9512 \\
Bakolori dam & 0.0049 & 22.6500 & 5.3850 & 91.2000 & 1902 & 10.0682 \\
Dangulbi dam & 0.0025 & 68.8000 & 8.6550 & 99.4500 & 1902 & 12.3297 \\
\hline
\end{tabular}

\section{REFERENCE}

Abdulrahman, MO; Reshma D'Souza, (2008). The effects of different methods of cooking on proximate, mineral and heavy metal composition of fish and shrimps consumed in the Arabian Gulf. Archivos Latinomericanos De Nutricion Organo Official de la Sociedad Latinoamericana de Nutricion 58(1) 103-109

Adebayo, KS; Rapheal, O (2011). "Survey of heavy metal contaminations of cassava mash and maize corns dried along the highways in some selected states in northern part of Nigeria, $A d v$. Appl. Sci. Res., 2 (5):561-571

Adefemi, OS; Asaolu SS; Olaofe O (2007). Assessment of the Physico-Chemical Status of Water Samples from Major Dams in Ekiti State, Nigeria. Pask. J. Nutr., 6 (6): 657-659.

Agency for Toxic Substances and Disease Registry (ATSDR) 1999. Lead. US Public Health Service.

Akabzaa, TM (2000). Boom and Dislocation: A Study of the Social and Environmental Impacts of Mining in the Wassa West District of Ghana. Third World Network, Africa Secretariat; Accra, Ghana.

American Public Health Association, (APHA) 2005, "Standard Methods for the Examination of Water and Wastewater," 21st Edition American Public Health Association,

Amoo, IA; Adebayo, OT; Lateef, AJ (2005). Evaluation of Heavy Metals in Fishes, Water and Sediments of Lake Kainji, Nigeria. J. Food. Agric. Environ. 8: 209-212 
Angula, E; 1996. The Tomlinson Pollution Index applied to heavy metal, Mussel-Watch data: A useful index to assess coastal pollution. Sci. Total Environ, 187, 19-56.

Armah, FA; Obiri S; Yawson DO; Pappoe ANM; Bismark A (2010). ). Evaluation of Heavy Metals in Fishes, Water and Sediments of Lake Kainji, Nigeria. J. Environ. Stat. 1:212-218.

Asaolu, SS; Ipinmoroti, KO; Adeyinwo, CE; Olaofe, O (1997): Seasonal Variation in heavy metal distribution in sediment of Ondo State Coastal Region. Ghana J. Chem. 3 (1) 11-16.

Ashokkumar S; Mayavu P; Samupathkumar P; Manivasagam P; Rajaram G (2009). Seasonal Distribution of Heavy Metals in the Mullipallam Creck of Muthupettai Manogroves (Southeast Coast of India). American - Eurasian J. Sci. Res. 4(4): 308-312.

Ayodele, JT; Gaya, UM (1994). Determination of Lead in Street Dust to Index its Pollution in Kano Municipal. Spectrum Journal, I: 94-97.

Bassey, FI; Iwegbue CMA; Obi-Iyeke, GE; Tesi GO; Rotu, AR; Gobe, OA; Tsafe AI (2014). Heavy metals in soils and tomatoes grown in urban fringe environment in Asaba, Delta state, Nigeria. Nig. J. Basic Appl. Sci. 22 (1\&2), p. 27-31.

Bhuiyan, MAH; L Parvez; MA Islam; SB Dampare; S Suzuki 2010. J. Hazard. Mate. 179, 10651077.

Bhupander K, Sanjay K, Meenu M, Prakash D, Singh SK, Sharma CS, Mukherjee DP (2011) Contrasting two methods for determining trace metal partitioning in oxidizable sediments. Arch. Appl. Sci. Res. 3:139-146.

Boamponsem LK; Adam JI; Dampare SB; OwusuAnsah E; Addae G (2010). Studies on the histopatholoigcal changes in selected tissues of fish Labeo rohita to phenol. J. Chem Pharm Res 2: 504527.

Bosiacki, M; Tyksinski, W (2009). Lead, Zinc, iron, and managanese content in edible parts of some fresh vegetables sold on markets in Pozincan. $J$. Elementol, 14, p. 13-22.

Chapman, PM; Allard PJ; Vigers GA (1999). Development of sediment quality values for Hong Kong special adminstrative region: A possible model for other jurisdictions. Mar. Pollute. Bull. 38: 161-169.

Duruibe, TO; Ogwuegbu MOC; Egwurugwu JN (2007). Practical Information on Surface Water Problems Int. J. Phys. Sci. 2: 112-118.

Galadima, A (2012). Arsenic level speciation in fresh water from Karaye Local Government Area, Kano State, Nigeria. Inter. J. Chem. 113-117.

Girigisu, S; Ibeanu IGE; Adeyemo DJ; Okoh S (2012). Methods for Physical and Chemical Analysis of Fresh Waters Amer. J. Appl. Sci. 9: 1014-1019.

Harada, M (1997). Neurotoxicity of Methyl-mercury: Minamata and the Amazon, in: Verity (eds), Mineral and Metal Neurotoxicology, CRC Press, Tokyo, pp. 177-188.

Harikumar PS; Jisha TS (2010). Effect of sugar factory effluent on glycogen, protein and free amino acid content in tissue of the fish Lepidocephalus thermalis Inter. J. Engineer. Sci. Technol. 2 (5), 840-850.

Johnson, AR; Munoz, A; Gottlieb, JL; Jarrard, DF (2007). High dose zinc increases hospital admissions due to genitourinary complications. $J$. Urol. 177 -.639-643.

Kakulu SE; Osibanjo O; Ajayi SO (1985). Trace metal content of Fish and Shellfishes of the Niger Delta of Nigeria. Environ. Inter. 13: 247-251.

Karadede, H; Unlu, E (2000). "Concentrations of Some Heavy Metals in Water, Sediment and Fish Species from the Atatu"rk Dam Lake (Euphrates), Turkey," Chemos- phere, 5(3), 1371-1376.

Kirmani, MZ; Sheikh, M; Farah, N; Iftikhar, IN; Erum, Z (2011). Determination of some toxic and essential trace metals in some medicinal and edible plants of Karachi city. J. Basic Appl. Sc., 3(4): 89-95.

Liu, HY; Probst, A; Liao, BH (2005), 'Metal contamination of soils and crops affected by the Changzhou lead/ zinc mine spill (Hunan, China)'. Sci. Total Environ. 339, 153-166.

Lottermoser, B (2007). Mine Wastes: Characterization, Treatment and Environmental Impacts. Springer; New York, NY, USA: pp. 1290. 
Manohara, B; Belagali, SL (2014). Characterization of essential nutreint and heavy metals during municipal solid waste composting Inter. J. Innov. Res. Sci. Engineer. Technol. 3 (2), 9664-9672.

Matshusa, K; Ogola, JS; Maas, K (2012). Dispersion of metals at Louis Moore gold tailings dam, Limpopo province, South Africa; Proceedings of the International Mine Water Association Symposium; Bunbury, Australia; pp. 334A$334 \mathrm{E}$.

Muchuweti, MJ; Birkett, JW; Chinyanga, E; Zvauya, R; Scrimshaw, M.D; and Lester, Muraleedharan; Antony, KP; Perigreen, PA; Gopakumar, K (2006). Utilization of unconventional fish resources for surimi preparation. Proceedings of the second workshop on scientific results of FORV SAGAR. Sampada. Dept. of Ocean development. New Delhi, (India). pp. 539-543
Okoye, BCO (1989). Levels and impact of some heavy metal in Lagos Lagoon. Ph.D Thesis O.A.U IleIfe.

Oktem, F; Yavrucuoglu, H; Turedi, A; Tune, B (2005). The effect of nutritional habits on hematological parameters and trace elements in children. Suleyman Demirel Univ.Tip Fak.Der. 12, p. 6-10. (In Turkish).

Rafiei B; Bakhtiari Nejad M; Hashemi, M; Khodaei, A (2010). Distribution of heavy metals around the Dashkasan Au mine. Int. J. Environ. Res.; 4:647654.

Valko, M; Rhodes, C; Moncol, J; Izakovic, M; Mazur, M (2006). Free radicals, metals and antioxidants in oxidative stress-induced cancer. Chem. Biol. Interact; 160:1-40. 